\title{
Chasing an Elusive Alkoxide: Attempts to Synthesize $\left[\mathrm{OC}(\mathrm{tBu})\left(\mathrm{CF}_{3}\right)_{2}\right]^{-}$
}

\author{
Lutz O. Müller§, Rosario Scopellitib , and Ingo Krossing ${ }^{\star a}$ \\ $\S$ SCS Poster Prize Winner
}

\begin{abstract}
The synthesis of the alkoxide $\left[\mathrm{OC}(t \mathrm{Bu})\left(\mathrm{CF}_{3}\right)_{2}\right]^{-}$by the reaction of $t \mathrm{BuM}$-reagents $(\mathrm{M}=\mathrm{Li} ; \mathrm{MgX})$ with hexafluoroacetone was attempted. This alkoxide was anticipated to be a good building block for novel weakly coordinating anions. However, in all attempted syntheses - also supported by theoretical DFT calculations - it was shown that $\left[\mathrm{H}^{-}\right.$addition is favored over $[t \mathrm{Bu}]^{-}$addition. Thus compounds like $\left[\left(\mathrm{Li}\left(\mathrm{OC}(\mathrm{H})\left(\mathrm{CF}_{3}\right)_{2}\right]_{4} \cdot 2 \mathrm{Et}_{2} \mathrm{O}(\mathbf{1})\right.\right.$ and $\left(\mathrm{CF}_{3}\right)_{2}(\mathrm{H}) \mathrm{COMgCl} \cdot\left(\mathrm{OEt}_{2}\right)_{2}(4)$ were formed. An unexpected result was the formation of $(\mathrm{THF})_{3} \mathrm{LiO}\left(\mathrm{CF}_{3}\right)_{2} \mathrm{OC}(\mathrm{H})\left(\mathrm{CF}_{3}\right)_{2}$ (2), an addition compound built from $\left[\left(\mathrm{CF}_{3}\right)_{2} \mathrm{C}(\mathrm{H}) \mathrm{O}\right]^{-}$and hexafluoroacetone. The alkoxy-alkoxide 2 could be useful for further applications.
\end{abstract}

Keywords: Alkoxide $\cdot$ DFT · Weakly coordinating anion (WCA)

\section{Introduction}

Weakly coordinating anions (WCAs) are useful for the stabilization of diverse applied [1] and fundamental [2] cations. WCAs have been continuously developed in the last two decades and were recently reviewed by one of us [3]. Frequently employed and commercially available WCAs are poly-and perfluorinated tetraarylborates $\left[\mathrm{B}\left(\mathrm{Ar}^{\mathrm{F}}\right)_{4}\right]^{-}\left(\mathrm{Ar}^{\mathrm{F}}=\mathrm{C}_{6} \mathrm{~F}_{5}[4], 3,5\left(\mathrm{CF}_{3}\right)_{2} \mathrm{C}_{6} \mathrm{H}_{3}\right.$ [5] and others [3]). However the borates with $\mathrm{Ar}^{\mathrm{F}}=\left(\mathrm{CF}_{3}\right)_{2} \mathrm{C}_{6} \mathrm{H}_{3}$ are chemically less robust [6] and those with $\mathrm{Ar}^{\mathrm{F}}=\mathrm{C}_{6} \mathrm{~F}_{5}$ need explosive materials during the synthesis $\left(\mathrm{C}_{6} \mathrm{~F}_{5} \mathrm{Li}\right)$ [3]. Carboranate anions of the type

${ }^{\star}$ Correspondence: Prof. Dr. I. Krossing ${ }^{a}$

Tel.: + 41216939315

Fax: + 41216939305

E-Mail: ingo.krossing@epfl.ch

aLaboratoire de chimie inorganique et de coordination

bX-ray structure determinations; Laboratoire de chimie supramoléculaire des lanthanides

Ecole Polytechnique Fédérale de Lausanne (EPFL)

Bâtiment de chimie $(\mathrm{BCH})$

Avenue Fôrel

$\mathrm{CH}-1015$ Lausanne
$\left[\mathrm{CB}_{11} \mathrm{X}_{\mathrm{n}} \mathrm{H}_{12-\mathrm{n}}\right](\mathrm{n}=1-12, \mathrm{X}=\mathrm{F}$ [7][8], $\mathrm{Cl}$, $\mathrm{Br}, \mathrm{I}$, [2] $\mathrm{CH}_{3}$ [9], $\mathrm{CF}_{3}$ [10]) are chemically very robust, but have disadvantages in the complex synthesis and the small scale. In our group we investigate easily accessible yet chemically robust WCAs of the type $\left[\mathrm{Al}\left(\mathrm{OR}^{\mathrm{F}}\right)_{4}\right]^{-}\left(\mathrm{R}^{\mathrm{F}}=\right.$ poly- and perfluorinated alkoxides, see Fig. 1) [11].

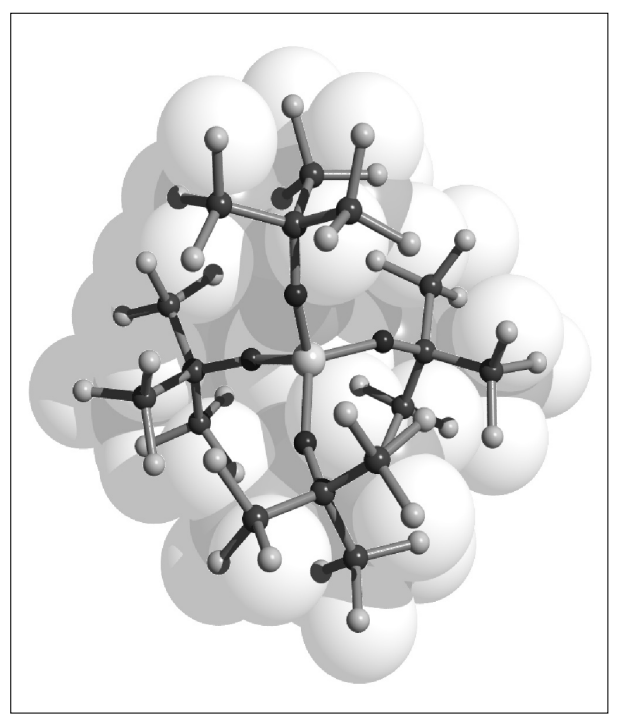

Fig. 1. The known WCA $\left[\mathrm{Al}\left(\mathrm{OR}^{\mathrm{F}}\right)_{4}\right]^{-}\left(\mathrm{R}^{\mathrm{F}}=\mathrm{C}\left(\mathrm{CF}_{3}\right)_{3}\right)$ [11]. By formal replacement of one $\mathrm{CF}_{3}$ group in each alkoxide by $t \mathrm{Bu}$, the proposed new WCA is obtained.

The $\mathrm{CF}_{3}$ groups form a smooth non-adhesive surface of the anion ('Teflon-coating'). Thus, in contrast to non-fluorinated alkoxyaluminates, the anion with $\mathrm{R}^{\mathrm{F}}=$ $\mathrm{C}\left(\mathrm{CF}_{3}\right)_{3}$ is stable in $\mathrm{H}_{2} \mathrm{O}$ and aqueous $\mathrm{HNO}_{3}$. $\mathrm{Li}\left[\mathrm{Al}\left(\mathrm{OR}^{\mathrm{F}}\right)_{4}\right]$ [11] can be synthesized from commercially available $\mathrm{LiAlH}_{4}$ and $\mathrm{HOR}^{\mathrm{F}}$ in $200 \mathrm{~g}$ scale within two days [12]; it may then easily and in high yield be converted into $\mathrm{Cs}^{+}-[13], \mathrm{Tl}^{+}-[14], \mathrm{Ag}^{+}-$ [11], $\mathrm{CPh}_{3}{ }^{+}-$[13], $\mathrm{H}\left(\mathrm{OEt}_{2}\right)_{2}{ }^{+}-[15]$ and other salts. These WCAs were used for the preparation of unusual weak Lewis acid base adducts [16-19] as well as electrophilic non-metal cations [20-23] but also enhance the activity of transition metal catalysts [24][25].

Due to the success of these aluminate WCAs, we were interested in broadening the basis of the known bulky fluorinated alkoxides. Therefore, the initial aim of this study was to synthesize an alternative $\left[\mathrm{Al}\left(\mathrm{OR}^{\mathrm{F}}\right)_{4}\right]^{-}$-anion with the new polyfluorinated alkoxy ligand $\mathrm{R}^{\mathrm{F}}=\mathrm{C}(t \mathrm{Bu})\left(\mathrm{CF}_{3}\right)_{2}$ (Fig. 1, Scheme 1, routes (1) and (2)).

In the new WCA we anticipated the oxygen atoms to be better shielded than in the current $\left[\mathrm{Al}\left(\mathrm{OR}^{\mathrm{F}}\right)_{4}\right]^{-}$-anion $\left(\mathrm{R}^{\mathrm{F}}=\right.$ $\left.\mathrm{C}\left(\mathrm{CF}_{3}\right)_{3}\right)$. This feature should lead to maximum anion stability.

\section{Results and Discussion}

\subsection{Syntheses and Spectroscopic Characterization}

Scheme 2 shows the identified products of the different reactions of hexafluoroacetone with $t \mathrm{BuLi}$ or $t \mathrm{BuMgX}(\mathrm{X}=\mathrm{Cl}$, I) as $t \mathrm{Bu}$ source. 


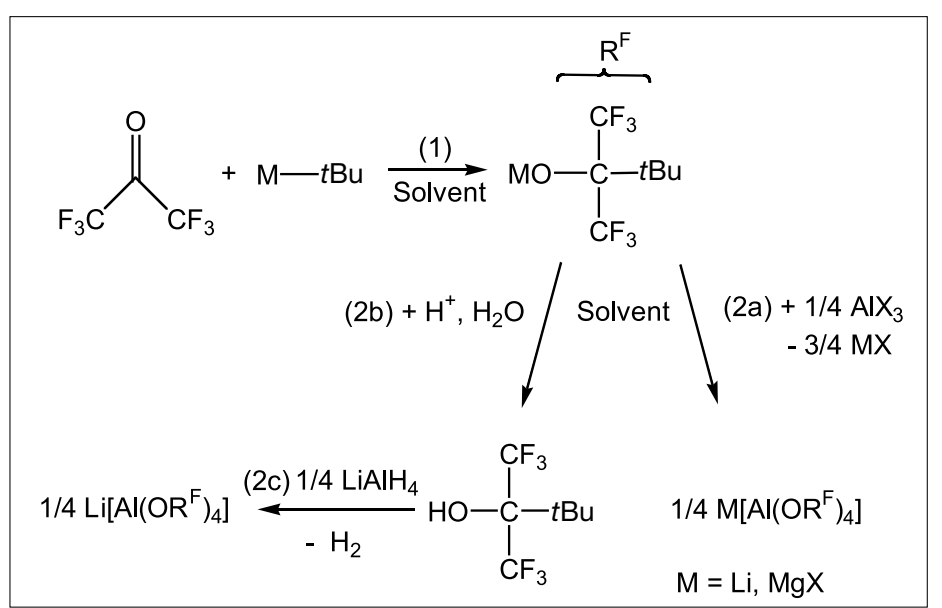

Scheme 1. Proposed syntheses of new $M\left[A l\left(\mathrm{OR}^{\mathrm{F}}\right)_{4}\right]$ salts with $\mathrm{R}^{\mathrm{F}}=$ $\mathrm{C}(t \mathrm{Bu})\left(\mathrm{CF}_{3}\right)_{2}$.

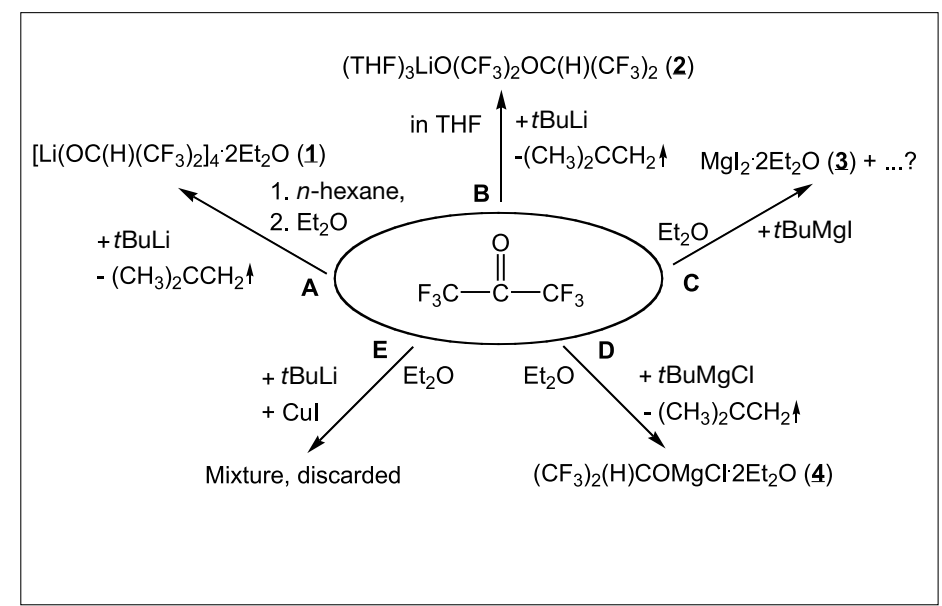

Scheme 2. Attempted syntheses of the new $\mathrm{MOR}^{\mathrm{F}}$ alkoxides with $\mathrm{R}^{\mathrm{F}}=$ $\mathrm{CtBu}\left(\mathrm{CF}_{3}\right)_{2}$; isolated products.
None of the attempted syntheses of the new alkoxide $\mathrm{MOR}^{\mathrm{F}}$ succeeded as anticipated. In route $\mathbf{A}$ hexafluoroacetone was condensed to a frozen solution of $t \mathrm{BuLi}$ in $\mathrm{n}$ hexane at $77 \mathrm{~K}$. After warming to $195 \mathrm{~K}$ and stirring overnight at room temperature the solvent was removed at $298 \mathrm{~K}$ by vacuum distillation and a colorless oil was isolated. The oil was recrystallized from $\mathrm{Et}_{2} \mathrm{O}$ and was spectroscopically and by $\mathrm{X}$-ray analysis identified as $\left[\mathrm{Li}\left(\mathrm{OC}(\mathrm{H})\left(\mathrm{CF}_{3}\right)_{2}\right]_{4} \cdot 2 \mathrm{Et}_{2} \mathrm{O}\right.$ (1) $\left(\delta^{1} \mathrm{H}\left(\left(\mathrm{CF}_{3}\right)_{2} \mathrm{C}-H\right)=4.41\right.$ (sep.)). The second route $\mathbf{B}$ proceeded similar to $\mathbf{A}$, but the solvent was changed from n-hexane to a n-hexane/THF mixture. After addition of $\left(\mathrm{CF}_{3}\right)_{2} \mathrm{CO}$ and warming first to $195 \mathrm{~K}$ (2 $\mathrm{h})$, then to $298 \mathrm{~K}(12 \mathrm{~h})$ the solvent was removed by vacuum distillation at $298 \mathrm{~K}$. The resulting yellow oil was recrystallized from THF. The colorless crystals were identified as $(\mathrm{THF})_{3} \mathrm{LiO}\left(\mathrm{CF}_{3}\right)_{2} \mathrm{OC}(\mathrm{H})$ $\left(\mathrm{CF}_{3}\right)_{2}(2)\left(\delta^{1} \mathrm{H}\left(\left(\mathrm{CF}_{3}\right)_{2} \mathrm{C}-\mathrm{H}\right)=4.41\right.$ (sep.) $)$. In structure 2 the two $\mathrm{C}\left(\mathrm{CF}_{3}\right)_{2}$ groups are dissimilar $\left(\delta^{19} \mathrm{~F}\left(\mathrm{O}_{2} \mathrm{C}\left(\mathrm{CF}_{3}\right)_{2}\right)=-76.2(\mathrm{~s})\right.$; $\left.\delta^{19} \mathrm{~F}\left(\mathrm{OC}(\mathrm{H})\left(\mathrm{CF}_{3}\right)_{2}\right)=-82.2(\mathrm{~s})\right)$. Thus, it appears that the solid-state structure remains intact in solution. Also the next route $\mathbf{C}$ with the Grignard $t$ BuMgI failed to proceed as hoped and the only identified product was a large amount of $\mathrm{MgI}_{2} \cdot 2 \mathrm{Et}_{2} \mathrm{O}(3)$.

Route $\mathbf{D}$ employed commercially available Grignard reagent. $t \mathrm{BuMgCl}$ dissolved in $\mathrm{Et}_{2} \mathrm{O}$ was frozen to $77 \mathrm{~K}$. Hexafluoroacetone was condensed onto the frozen liquid and allowed to slowly warm with stirring to $298 \mathrm{~K}$. After removing the solvent a white precipitate was formed. On the basis of the NMR-data and the weight balance this white precipitate was assigned as $\left(\mathrm{CF}_{3}\right)_{2}(\mathrm{H}) \mathrm{COMgCl} \cdot 2 \mathrm{Et}_{2} \mathrm{O}$ (4) $\left(\delta^{1} \mathrm{H}\left(\left(\mathrm{CF}_{3}\right) 2 \mathrm{C}-H\right)=5.38\right.$ (br., sept. $) ; \delta^{19} \mathrm{~F}$ $\left.\mathrm{C}\left(\mathrm{CF}_{3}\right)_{2}=-75.1(\mathrm{~s})\right)$. In route $\mathbf{E} \mathrm{CuI}$ was added to the $t \mathrm{BuLi}$ in order to use the gentler organocuprates as alkylating agent [26]. ${ }^{1} \mathrm{H}$ NMR spectroscopic analyses of several reactions revealed the presence of complex mixtures, which were discarded (several broad singlets at $\delta^{1} \mathrm{H} \approx 4.3\left(\mathrm{CF}_{3}\right) 2 \mathrm{C}-H$ ?), several singlets at $\delta^{1} \mathrm{H} \approx 1.2(t \mathrm{Bu}$ ?)).

In summary we demonstrated that neither the reagent $t \mathrm{BuLi}$ nor the Grignards $t \mathrm{BuMgX}$ add to the electrophilic carbonyl atom of $\left(\mathrm{CF}_{3}\right)_{2} \mathrm{CO}$. In general, both rather act as $\mathrm{H}^{-}$donors. Thus, unfortunately the preparation of $\left[\mathrm{OC} \mathrm{Bu}\left(\mathrm{CF}_{3}\right)_{2}\right]^{-}$proved impossible with all conditions tried.

The solvent-dependent formation of 1 and 2 may be understood by the initial addition of $\mathrm{H}^{-}$to $\left(\mathrm{CF}_{3}\right)_{2} \mathrm{CO}$ to give the $\left[\left(\mathrm{CF}_{3}\right)_{2} \mathrm{C}(\mathrm{H}) \mathrm{O}\right]^{-}$-alkoxide, which in THF may coordinate another $\left(\mathrm{CF}_{3}\right)_{2} \mathrm{CO}$ to give 2 (Scheme 3).

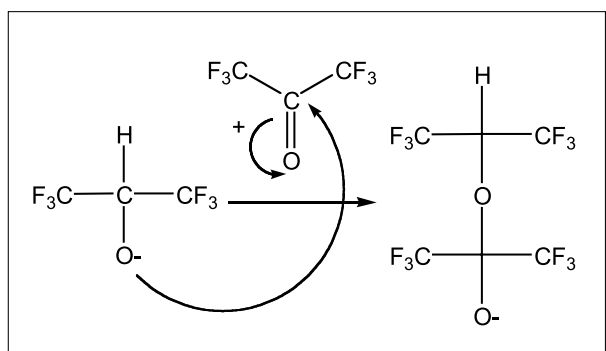

Scheme 3. Coordination of a hexafluoroacetone molecule by the alkoxide $\left[\left(\mathrm{CF}_{3}\right)_{2} \mathrm{C}(\mathrm{H}) \mathrm{O}\right]^{-}$produces the anion in 2.

The reason for this solvent selectivity may be due to the stronger donor capacity of THF that breaks up the tetrameric structure (1) and thus increases the nucleophilicity of the alkoxide oxygen atom.

\subsection{Crystal Structures}

The crystal structure of $\left[\mathrm{Li}\left(\mathrm{OC}(\mathrm{H})\left(\mathrm{CF}_{3}\right)_{2}\right]_{4} \cdot 2 \mathrm{Et}_{2} \mathrm{O}(\mathbf{1})\right.$ is shown in Fig. 2 [27]. Compound 1 forms a slightly distorted $(\mathrm{Li}-\mathrm{O})_{4}$ heterocubane $(<(\mathrm{O}-\mathrm{Li}-$ $\left.\mathrm{O})_{\text {av. }} 94.34^{\circ} ;<(\mathrm{Li}-\mathrm{O}-\mathrm{Li})_{\text {av. }} 85.32^{\circ}\right)$. Two of the four $\mathrm{Li}$ atoms are coordinated by $\mathrm{Et}_{2} \mathrm{O}$ molecules. Such a heterocubane structure is a general structural feature of $\mathrm{Li}$ alkoxides and is a result of the high electrophilicity of the small lithium ion. In this structure $\mathrm{Li}$ is either coordinated by four oxygen atoms $(d(\mathrm{Li}-\mathrm{O})=1.87 \AA$ to $2.01 \AA)$ or it additionally interacts with fluorine atoms $(d(\mathrm{Li}-\mathrm{F})$ $=2.15 \AA$ to $2.38 \AA$ ).

In the related structure $\left[\mathrm{Li}\left(\mathrm{OCH}_{2} \mathrm{CF}_{3}\right)\right]_{4}(\mathrm{THF})_{3}[28]$ the Li-O distances range from 1.87 to 1.97 [ $\mathrm{A}]$. The coordinated neutral $\mathrm{Et}_{2} \mathrm{O}$ molecules exhibit rather short $\mathrm{Li}-\mathrm{O}$ distances $(d(\mathrm{Li}-\mathrm{O})$ $=1.92,1.95 \AA$, cf. $d\left(\mathrm{Li}-\mathrm{O}_{\text {alkoxide }}\right)=1.87$ to $2.01[\AA]$ ). This demonstrates the weakly basic nature of the alkoxide oxygen atoms that - although being negatively charged and thus expected to interact more strongly with the $\mathrm{Li}$ atoms - exhibit similar $\mathrm{Li}-\mathrm{O}$ bond lengths to the neutral, and therefore on first sight weaker, oxygen donor $\mathrm{Et}_{2} \mathrm{O}$. Fig. 3 shows the molecular structure of 2 [29]. In contrast to 1,2 exhibits a structure in which one hexafluoroacetone molecule is coordinated to a $\left[\left(\mathrm{CF}_{3}\right)_{2} \mathrm{C}(\mathrm{H}) \mathrm{O}\right]^{-}$alkoxide (see Fig. 3). It is the first known structure of a fluorinated alkoxy-alkoxide.

The $\mathrm{Li}-\mathrm{O}$ distances to the coordinated THF donors are similar and average 1.95 $\AA$. The Li-alkoxide distance $\mathrm{Li}(1)-\mathrm{O}(1)$ is by $0.14 \AA$ shorter than the other Li-O separations. The distance between $\mathrm{C}(1)-\mathrm{O}(1)$ $(1.28 \AA)$ is much shorter than $\mathrm{C}(1)-\mathrm{O}(2)$ $(1.51 \AA)$. This may be compared to the average $\mathrm{C}=\mathrm{O}$ distance in acetone $(1.21 \AA)$ [30] as well as the average $\mathrm{C}-\mathrm{O}$ distance in $\mathbf{1}$ of $1.38 \AA$. The unusual $\mathrm{C}-\mathrm{O}$ distances in $\mathbf{2}$ may be rationalized by the following resonance structures (Scheme 4).

\subsection{DFT Calculations}

To understand if the observed $\mathrm{H}^{-}$addition of $t \mathrm{BuLi}$ to the carbonyl atom of hexafluoroacetone is due to kinetics (9 equiv. $\mathrm{H}$ 


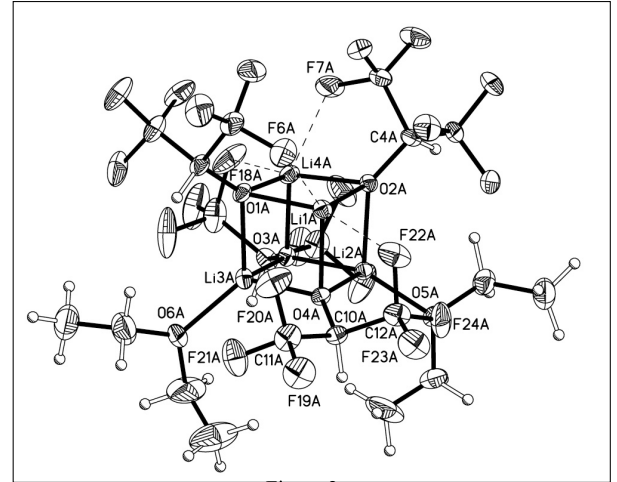

Fig. 2. Section of the crystal structure of $\left[\mathrm{Li}\left(\mathrm{OC}(\mathrm{H})\left(\mathrm{CF}_{3}\right)_{2}\right]_{4} \cdot 2 \mathrm{Et}_{2} \mathrm{O}\right.$ (1). The atoms of the structure are shown as thermal ellipsoids with a probability of $20 \%$. Only $\mathrm{H}$ atoms are shown as small circles of an arbitrary scale. Some selected distances $[\AA \AA]$ : $\mathrm{Li}(3 \mathrm{~A})-\mathrm{O}(4 \mathrm{~A})$ 1.962(9); $\mathrm{Li}(3 \mathrm{~A})-\mathrm{O}(3 \mathrm{~A})$ 1.965(10); $\mathrm{Li}(3 \mathrm{~A})-\mathrm{O}(1 \mathrm{~A})$ 1.984(10); $\mathrm{Li}(2 \mathrm{~A})-\mathrm{O}(4 \mathrm{~A})$ 1.976(9); $\mathrm{Li}(2 \mathrm{~A})-\mathrm{O}(3 \mathrm{~A}) \quad$ 1.962(9); $\mathrm{Li}(2 \mathrm{~A})-\mathrm{O}(2 \mathrm{~A})$ 2.016(10); $\mathrm{Li}(1 \mathrm{~A})-\mathrm{O}(4 \mathrm{~A})$ 1.950(10); $\mathrm{Li}(1 \mathrm{~A})-\mathrm{O}(2 \mathrm{~A})$ 1.878(10); $\mathrm{Li}(1 \mathrm{~A})-\mathrm{O}(1 \mathrm{~A})$ 1.946(9); $\mathrm{Li}(3 \mathrm{~A})-\mathrm{O}(6 \mathrm{~A})$ 1.927(10); $\mathrm{Li}(2 \mathrm{~A})-\mathrm{O}(5 \mathrm{~A})$ 1.957(9); $\mathrm{O}(4 \mathrm{~A})-\mathrm{C}(10 \mathrm{~A})$ 1.380(6); $\quad \mathrm{Li}(4 \mathrm{~A})-\mathrm{F}(7 \mathrm{~A}) \quad 2.171(10) ; \quad \mathrm{Li}(1 \mathrm{~A})-\mathrm{F}(6 \mathrm{~A})$ 2.157(10); Li(1A)-F(22A) 2.388(10); C-C 1.273(1)1.525(9) (Ø: 1.453(1)); C-F 1.306(9)-1.374(8) (Ø: $1.334(9))$.

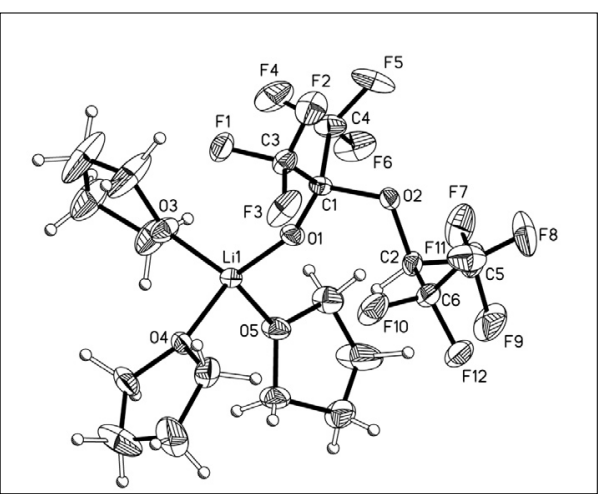

Fig. 3. Molecular structure of $(\mathrm{THF})_{3} \mathrm{LiO}\left(\mathrm{CF}_{3}\right)_{2} \mathrm{OC}$ $(\mathrm{H})\left(\mathrm{CF}_{3}\right)_{2}$ (2). The atoms of the structure are shown as thermal ellipsoids with a probability of $25 \%$. The $\mathrm{H}$ atoms are shown as small circles of an arbitrary scale. Selected bond lengths $[\AA \AA]$ and angles ["] of (2): $\mathrm{Li}(1)-\mathrm{O}(1) 1.810(7) ; \mathrm{Li}(1)-\mathrm{O}(4)$ 1.950(7); Li(1)-O(5) 1.968(8); Li(1)-O(3) 1.938(8); $\mathrm{O}(1)-\mathrm{C}(1)$ 1.282(5); $\mathrm{C}(1)-\mathrm{O}(2)$ 1.507(5); $\mathrm{O}(2)-\mathrm{C}(2)$ 1.417(5); $C(1)-C(4)$ 1.559(6); C-F 1.300(7)1.345(6) (Ø: 1.32(3)). Li(1)-O(1)-C(1) 157.1(3); $\mathrm{C}(1)-\mathrm{O}(2)-\mathrm{C}(2)$ 114.4(3); O(1)-C(1)-O(2) 114.9(3).

atoms for $\mathrm{H}^{-}$addition and isobutene elimination) or thermodynamics, we fully optimized [31][32] the structures of tetrameric $(t \mathrm{BuLi})_{4}$, hexafluoroacetone, as well as the $\mathrm{H}^{-}$and $t \mathrm{Bu}^{-}$addition products and the eliminated isobutene at the BP86/SV(P) level of theory [33][34] with the program Turbomole. Then we analyzed the thermodynamics of the two possible reactions with inclusion of zero point energy, thermal contributions to the enthalpy/entropy and solvation effects with the COSMO [35][36] model (Table).

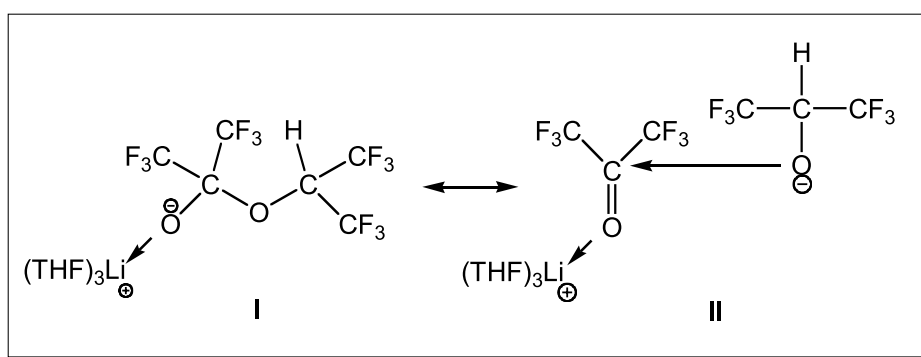

Scheme 4. Two important resonance structures to rationalize the structural parameters of 2 . In the resonance structure I all three $\mathrm{C}-\mathrm{O}$ bond lengths tend to be similar, but according to structure II significantly different C$O$ bond lengths with bond orders $>>1.0$ and $<<1.0$ can be expected. It appears that II has more weight to describe compound 2 .
The calculated thermodynamics in the Table show that the preference of $\mathrm{H}^{-}$over $t \mathrm{Bu}^{-}$addition to hexafluoroacetone is not only kinetic but also thermodynamic. Thus it appears that other routes than $\mathrm{M} t \mathrm{Bu}$ addition have to be used to induce $\left[\mathrm{OC} t \mathrm{Bu}\left(\mathrm{CF}_{3}\right)_{2}\right]^{-}$formation.

\section{Conclusion}

With this work we showed that neither $t \mathrm{BuLi}$ nor $t \mathrm{BuMgX}$ add a $t \mathrm{Bu}$-group to the electrophilic carbonyl atom of hexafluoroacetone. DFT calculations showed that $\mathrm{H}^{-}$addition is kinetically and thermodynamically favored. Thus, to achieve the synthesis of the desired $\left[\mathrm{OCt} \mathrm{Bu}\left(\mathrm{CF}_{3}\right)_{2}\right]^{-}$ alkoxide, which is of interest for the production of new WCAs of type $\left[\mathrm{Al}\left(\mathrm{OR}^{\mathrm{F}}\right)_{4}\right]^{-}$, other routes have to be found. However, the straight forward but unexpected synthesis of the first fluorinated alkoxy-alkoxide $\mathbf{2}$ may be of importance for further WCA syntheses, if a weak oxygen donor is desired in the periphery of the WCA.

\section{Experimental Section}

\subsection{General Procedures}

Due to the air- and moisture-sensitivity of most materials all manipulations were undertaken using standard vacuum and Schlenk techniques as well as in a glove box with a nitrogen atmosphere $\left(\mathrm{H}_{2} \mathrm{O}\right.$ and $\mathrm{O}_{2}<1 \mathrm{ppm}$ ). All solvents were dried by conventional drying agents and distilled af- terwards. Solution NMR spectra for 1 were recorded in $\mathrm{CDCl}_{3}$, for 2 in $\mathrm{CDCl}_{3} / \mathrm{Et}_{2} \mathrm{O}$, for 3 in $\mathrm{CD}_{2} \mathrm{Cl}_{2}$ and for 4 in acetone- $\mathrm{d}_{6}$ at room temperature on a Bruker AVANCE 400 spectrometer; data are given in ppm relative to the solvent signals, $\mathrm{CF}_{3} \mathrm{Cl}\left({ }^{19} \mathrm{~F}\right)$ and $\mathrm{LiCl}\left({ }^{7} \mathrm{Li}\right)$. IR spectra were obtained in nujol mull between CsI plates on a Bruker Vertex 70 IR spectrometer.

\subsection{Preparation of $\left[\mathrm{Li}\left(\mathrm{OC}(\mathrm{H})\left(\mathrm{CF}_{3}\right)_{2}\right]_{4} \cdot 2 \mathrm{Et} \mathrm{O}_{2} \mathrm{O}(1)\right.$}

Approximately $30 \mathrm{ml} \mathrm{n}$-hexane were added to a solution of $9.2 \mathrm{ml} \mathrm{(15.62}$ mmol) $t$ BuLi ( $=1.7 \mathrm{~mol} / \mathrm{l}$ in $\mathrm{n}$-hexane). Onto the frozen mixture $3.11 \mathrm{~g}$ (18.74 mmol, 1.2 equiv.) hexafluoroacetone was condensed at $77 \mathrm{~K}$. It was warmed up to $195 \mathrm{~K}$ and - with stirring overnight - to room temperature. Then the solvent was removed by vacuum distillation and the resulting colorless oil (4.03 g) isolated and crystallized from $\mathrm{Et}_{2} \mathrm{O}$. The structure of the colorless crystals was identified as $\left[\mathrm{Li}\left(\mathrm{OC}(\mathrm{H})\left(\mathrm{CF}_{3}\right)_{2}\right]_{4} \cdot 2 \mathrm{Et}_{2} \mathrm{O} \quad\right.$ (1) $\quad\left(\mathrm{m}_{\text {crystals }}\right.$ : $1.25 \mathrm{~g} ; 48 \%$ vs. hexafluoroacetone). The NMR spectra of these crystals and the supernatant solution are similar and indicate complete transformation to (1). ${ }^{1} \mathrm{H}$ NMR (400 MHz): $\delta=1.1(\mathrm{t}, 12 \mathrm{H}), 3.4(\mathrm{q}, 8 \mathrm{H})$, 4.41 (sep., $4 \mathrm{H}) ;{ }^{19} \mathrm{~F}$ NMR (376 MHz) $\delta=$ $-75(\mathrm{~s}, 6 \mathrm{~F}) ;{ }^{13} \mathrm{C}\left\{{ }^{1} \mathrm{H}\right\}(100 \mathrm{MHz}) \delta=29.9$ (s), $53.3(\mathrm{~s}), 73.9$ (broad), $124.4\left(\mathrm{q},{ }^{1} \mathrm{~J}_{\mathrm{C} . \mathrm{F}}\right.$ $=291.2 \mathrm{~Hz}) ;{ }^{7} \mathrm{Li}$ NMR $(155 \mathrm{MHz}) 5.7$ (s, 1Li); IR (CsI plates, nujol): $v=470(\mathrm{w})$, $553(\mathrm{w}), 558(\mathrm{w}), 636(\mathrm{w}), 689(\mathrm{~s}), 707(\mathrm{~s})$ 740 (s), 795 (vw), 852 (s), 890 (s), 920 (s), 959 (s), 973 (s), 1009 (w), 1087 (vs), 1199
Table. Thermodynamics of $\mathrm{H}^{-}$and $t \mathrm{Bu}^{-}$addition to hexafluoroacetone (all values are given in $\mathrm{kJ}$ / $\mathrm{mol})$

$\begin{array}{llll}\text { Reaction } & \Delta_{r} H^{\circ}(\mathrm{g}) & \Delta_{\mathrm{r}} \mathrm{G}^{\circ}(\mathrm{g}) & \Delta_{\mathrm{r}} \mathrm{G}^{\circ}(\mathrm{solv}) \\ (t \mathrm{BuLi})_{4}+\left(\mathrm{F}_{3} \mathrm{C}\right)_{2} \mathrm{CO} \rightarrow\left(\mathrm{F}_{3} \mathrm{C}\right)_{2}(t \mathrm{Bu}) \mathrm{COLi} & -294 & -229 & -211 \\ (t \mathrm{BuLi})_{4}+\left(\mathrm{F}_{3} \mathrm{C}\right)_{2} \mathrm{CO} \rightarrow\left(\mathrm{F}_{3} \mathrm{C}\right)_{2}(\mathrm{H}) \mathrm{COLi}+\mathrm{C}_{4} \mathrm{H}_{8} & -235 & -234 & -227\end{array}$


(vs), 1260 (vs), 1289 (vs), 1374 (vs), 1450 (w), 1475 (w), 1488 (vw) $\mathrm{cm}^{-1}$.

\subsection{Preparation of $(\mathrm{THF})_{3} \mathrm{LiO}\left(\mathrm{CF}_{3}\right)_{2} \mathrm{OC}\left(\mathrm{H}_{)}\left(\mathrm{CF}_{3}\right)_{2}(2)\right.$}

Approximately $30 \mathrm{ml}$ THF were added to a solution of $12 \mathrm{ml}(20.45 \mathrm{mmol}) t \mathrm{BuLi}(\mathrm{c}$ $=1.7 \mathrm{~mol} / \mathrm{l}$ in $\mathrm{n}$-hexane). The mixture forms a yellow solution, which was frozen to 77 $\mathrm{K}$. After condensing $4.08 \mathrm{~g}(24.58 \mathrm{mmol}$, 1.2 equiv.) hexafluoroacetone onto the frozen mixture and warming to $195 \mathrm{~K}$ with stirring, the yellow color of the mixture disappeared. The stirred mixture was allowed to slowly reach room temperature. After 24 $\mathrm{h}$ the solvent was removed by vacuum distillation at $298 \mathrm{~K}$. The resulting yellow oil $(3.3 \mathrm{~g})$ was crystallized from THF at 233 $\mathrm{K}$. The structure was identified as $(\mathrm{THF})_{3}$ $\mathrm{LiO}\left(\mathrm{CF}_{3}\right)_{2} \mathrm{OC}(\mathrm{H})\left(\mathrm{CF}_{3}\right)_{2}(2)\left(\mathrm{m}_{\text {crystals }}: 1.35\right.$ $\mathrm{g} ; 40 \%$ vs. hexafluoroacetone). The NMR spectra of these crystals and the supernatant solution are similar and indicate complete transformation to (2). ${ }^{1} \mathrm{H}$ NMR (400 MHz): $\delta=1.85(\mathrm{~m}, 4 \mathrm{H}), 3.71$ (m, 4H), 4.41 (sep., $1 \mathrm{H}) ;{ }^{19} \mathrm{~F} \mathrm{NMR}(376 \mathrm{MHz}) \delta=-76.2(\mathrm{~s}, 6 \mathrm{~F})$, $-82.2(\mathrm{~s}, 6 \mathrm{~F}) ;{ }^{7} \mathrm{Li}$ NMR $(155 \mathrm{MHz})-3.8(\mathrm{~s}$, $1 \mathrm{Li}) ;{ }^{13} \mathrm{C}\left\{{ }^{1} \mathrm{H}\right\}(100 \mathrm{MHz}) \delta=24.9$ (s), 68.4 (s), $122.6\left(\mathrm{q},{ }^{1} \mathrm{~J}_{\mathrm{C}, \mathrm{F}}=292.2 \mathrm{~Hz}\right), 122.9(\mathrm{q}$, ${ }^{1} \mathrm{~J}_{\mathrm{C}, \mathrm{F}}=291.8 \mathrm{~Hz}$ ); IR (CsI plates, nujol): v $=460(\mathrm{vw}), 530(\mathrm{vw}), 688(\mathrm{w}), 722(\mathrm{w}), 807$ (vw), $878(w), 895(w), 920(w), 959(\mathrm{~s})$, 1053 (s), 1103 (w), 1195 (vs), 1211 (vs), 1284 (s), 1381 (w), 1421 (w), 1459 (w), 1508 (vw) $\mathrm{cm}^{-1}$.

\subsection{Preparation of $\left(\mathrm{CF}_{3}\right)_{2}(\mathrm{H}) \mathrm{COMg}^{2} \mathrm{Et}_{2} \mathrm{O}(4)$}

$20 \mathrm{ml}(40 \mathrm{mmol})$ of colorless $t \mathrm{BuMgCl}$ ( $\mathrm{c}=2 \mathrm{~mol} / \mathrm{l}$ in $\mathrm{Et}_{2} \mathrm{O}$ ) were frozen to $77 \mathrm{~K}$, then $7.31 \mathrm{~g}$ (44 mmol, 1.1 equiv.) hexafluoroacetone were condensed onto the solid. The mixture was allowed to slowly reach room temperature with stirring. After removal of the solvent by vacuum distillation, a white precipitate formed. On the basis of the NMR data and the mass balance, the substance was assigned as $\left(\mathrm{CF}_{3}\right)_{2}(\mathrm{H}) \mathrm{COMgCl} \cdot 2 \mathrm{Et}_{2} \mathrm{O}$ (4) (m $\mathrm{m}_{\text {precipitate }}$ : $10.86 \mathrm{~g}, 96 \%) .{ }^{1} \mathrm{H}$ NMR (400 MHz): $\delta$ $=1.41(\mathrm{t}, 12 \mathrm{H}), 3.69$ (q, 8H), 5.38 (sept., $1 \mathrm{H}) ;{ }_{19} \mathrm{~F} \mathrm{NMR}(376 \mathrm{MHz}) \delta=-75.1(\mathrm{~s}, 6 \mathrm{~F})$; ${ }^{13} \mathrm{C}\left\{{ }^{1} \mathrm{H}\right\}(100 \mathrm{MHz}) \delta=67.0(\mathrm{~s}), 15.3(\mathrm{~s})$, 72.9 (broad), $124.2\left(\mathrm{q},{ }^{1} \mathrm{~J}_{\mathrm{C} . \mathrm{F}}=291.1 \mathrm{~Hz}\right)$; IR (CsI plates, nujol): $v=529(\mathrm{w}), 645(\mathrm{vw})$, 690 (w), 722 (w), 745 (w), $782(w), 857$ (w), 894 (w), 968 (vw), 1001 (vw), 1042 (w), 1099 (s), 1152 (s), 1188 (s), 1234 (s), 1297 (s), 1377 (vs), 1458 (vs) $\mathrm{cm}^{-1}$.

\subsection{X-ray Structure Determination}

Suitable crystals of $\mathbf{1}$ and $\mathbf{2}$ were formed by cooling a solution in $\mathrm{Et}_{2} \mathrm{O}$ and THF to 233 K. Data were collected on a Oxford
Diffraction KUMA4 CCD with Kappa geometry goniometer at $140 \mathrm{~K}$. Single crystals were mounted in perfluoroether oil on top of glass fiber and then placed in the cold stream of low-temperature device so that the oil solidified. Unit-cell parameters were calculated from a least-squares refinement of the setting angles of 5000 reflections collected. The structures were solved with direct methods in SHELXS [24][37] and successive interpretation of the difference Fourier maps using SHELXL-97. Refinement against $F^{2}$ was carried out with SHELXL-97. All non-hydrogen atoms were included anisotropically in the refinement.

\section{Received: February 19, 2006}

[1] E.Y.-X. Chen, T.J. Marks, Chem. Rev. 2000, 100, 1391.

[2] C.A. Reed, Acc. Chem. Res. 1998, 31, 325.

[3] I. Krossing, I. Raabe, Angew. Chem., Int. Ed. 2004, 43, 2066.

[4] A.G. Massey, A.J. Park, J. Organomet. Chem. 1964, 2, 245.

[5] H. Nishida, N. Takada, M. Yoshimura, T. Sonoda, H. Kobayashi, Bull. Chem. Soc. Jpn. 1984, 57, 2600.

[6] W.V. Konze, B.L. Scott, G.J. Kubas, Chem Commun. 1999, 1807.

[7] S.M. Ivanova, S.V. Ivanov, S.M. Miller, O.P. Anderson, K.A. Solntsev, S.H Strauss, Inorg. Chem. 1999, 38, 3756.

[8] S.V. Ivanov, J.J. Rockwell, O.G. Polyakov, C.M. Gaudinski, O.P. Anderson, K.A. Solntsev, S.H. Strauss, J. Am. Chem. Soc. 1998, 120, 4224.

[9] B.T. King, Z. Janousek, B. Gruener, M. Trammell, B.C. Noll, J. Michl, J. Am. Chem. Soc. 1996, 118, 3313.

[10] B.T. King, J. Michl, J. Am. Chem. Soc. 2000, 122, 10255 .

[11] I. Krossing, Chem. Eur. J. 2001, 7, 490.

[12] I. Krossing, A. Reisinger, Coord. Chem. Rev. 2006, in press.

[13] I. Krossing, H. Brands, R. Feuerhake, S Koenig, J. Fluorine Chem. 2001, 112, 83.

[14] M. Gonsior, I. Krossing, N. Mitzel, Z. Anorg. Allg. Chem. 2002, 628, 1821.

[15] I. Krossing, A. Reisinger, Eur. J. Inorg. Chem. 2005, 1979.

[16] T.S. Cameron, A. Decken, I. Dionne, M. Fang, I. Krossing, J. Passmore, Chem. Eur. J. 2002, 8, 3386.

[17] A. Adolf, M. Gonsior, I. Krossing, J. Am. Chem. Soc. 2002, 124, 7111.

[18] I. Krossing, A. Reisinger, Angew. Chem Int. Ed. 2003, 42, 5725 .

[19] I. Krossing, M. Gonsior, S. Antonijevic, Chem. Eur. J. 2006, 12, 1997.

[20] M. Gonsior, I. Krossing, L. Müller, I. Raabe, M. Jansen, L. Van Wüllen, Chem. Eur J. 2002, 8, 4475.

[21] I. Krossing, A. Bihlmeier, I. Raabe, N. Trapp, Angew. Chem. Int. Ed. 2003, 42 , 1531
[22] I. Krossing, M. Gonsior, E. Matern, Chem. Eur. J. 2006, 12, 1986.

[23] I. Krossing, M. Gonsior, E. Matern, Chem. Eur. J. 2006, 12, 1703.

[24] C. Boeing, G. Francio, W. Leitner, $A d v$. Syn. Cat. 2005, 347, 1537.

[25] S.P. Smidt, N. Zimmermann, M. Studer, A. Pfaltz, Chem. Eur. J. 2004, 10, 4685.

[26] J.A. Barth, Organikum 1996, 20, 546.

[27] Crystal-structure determination of $\left[\mathrm{Li}\left(\mathrm{OC}(\mathrm{H})\left(\mathrm{CF}_{3}\right)_{2}\right]_{4} \cdot 2 \mathrm{Et}_{2} \mathrm{O}: \mathrm{T}=140(2)\right.$ $\mathrm{K}$, Lorentz, polarization, and numerical absorption corrections, P21/n, Z = $8, \mathrm{a}=10.7940(12), \mathrm{b}=33.443(4), \mathrm{c}=$ 19.0211(16) $\AA, \beta=101.410(9)^{\circ} ; \mathrm{V}=$ 6730.6(12) $\AA^{3}, \mu=0.807 \mathrm{~cm}^{-1}, \rho_{\text {calc }}=$ $1.666 \mathrm{Mgm}^{-3}, 2 \theta \max =25^{\circ}$, reflections: 38871 collected, 11239 unique $\left(\mathrm{R}_{\text {int }}=\right.$ $0.0508), \mathrm{R}_{1}=0.1064, \mathrm{wR}_{2}($ all data $)=$ $0.3207, \mathrm{GOF}=1.124 . \mathrm{CCDC}=293664$ contains the supplementary crystallographic data for this paper. These data can be obtained free of charge from The Cambridge Crystallographic Data Centre via www.ccdc.cam.ac.uk/data_request/cif.

[28] T.J. Boyle, T.M. Alam, K.P. Peters, M.A. Rodriguez, Inorg. Chem. 2001, 40, 6281.

[29] Crystal-structure determination of $(\mathrm{THF})_{3} \mathrm{LiO}\left(\mathrm{CF}_{3}\right)_{2} \mathrm{OC}(\mathrm{H})\left(\mathrm{CF}_{3}\right)_{2}: \mathrm{T}=$ $140(2) \mathrm{K}$, Lorentz, polarization, and numerical absorption corrections, P21/n, Z $=4, \mathrm{a}=9.6874(15), \mathrm{b}=16.8076(19), \mathrm{c}=$ 15.0706(17) $\AA, \beta=90.477^{\circ} ; \mathrm{V}=2453.7(6)$ $\AA^{3}, \mu=0.807 \mathrm{~cm}^{-1}, \rho$ calc $=1.506 \mathrm{Mgm}^{-}$ $3,20 \max =25^{\circ}$, reflections: $13843 \mathrm{col}-$ lected, 4207 unique $\left(\mathrm{R}_{\text {int }}=0.0508\right), \mathrm{R}_{1}$ $=0.0815, w_{2}($ all data $)=0.2451, \mathrm{GOF}=$ 1.114. $\mathrm{CCDC}=293665$ contains the supplementary crystallographic data for this paper. These data can be obtained free of charge from The Cambridge Crystallographic Data Centre via www.ccdc.cam. ac.uk/data_request/cif.

[30] Typical interatomic distances, 'International Tables of Crystallography', Vol. C, 1999, 797.

[31] R. Ahlrichs, M. Baer, M. Haeser, H. Horn, C. Koelmel, Chem. Phys. Lett. 1989, 162, 165.

[32] M. von Arnim, R. Ahlrichs, J. Chem. Phys. 1999, 111, 9183.

[33] A.D. Becke, Phys. Rev. A 1988, 38, 3098.

[34] M. Levy, J.P. Perdew, J. Chem. Phys. 1986, $84,4519$.

[35] A. Klamt, G. Schüürmann, J. Chem. Soc., Perkin Trans. 2 1993, 799.

[36] A. Schäfer, A. Klamt, D. Sattel, J.C.W. Lohrenz, F. Eckert, Phys. Chem. Chem. Phys. 2000, 2, 2187.

[37] G.M. Sheldrick, SHELX software suite, University of Göttingen, Germany. 